\title{
Photodynamic Activity of Compounds Structurally Related to Cercosporin
}

\author{
F. MACRì and A. ViANELlo \\ Centro di Studio dei Problemi Fitopatologici della Barbabietola da Zucchero, CNR, \\ Unità di Ricezca del Progetto Finalizzato Chimica Fine e Secondaria, \\ Istituto di Patologia Vegetale, Università di Padova, I-35100 Padova, Italy
}

Received July 30, 1980

\begin{abstract}
The photodynamic activity of three compounds structurally related to cercosporin (isocercosporin, phleichrome, iso-phleichrome) and rubellin, a pigment possessing an anthraquinone-like structure, was studied. As previously reported for cercosporin, iso-cercosporin, phleichrome, iso-phleichrome and rubellin, when irradiated by an incandescent lamp, induced oxygen uptake and malondialdehyde (MDA) formation in pea stem and rat liver mitochondria and microsomes. All these compounds were also capable of inhibiting MDA formation induced by the peroxidizing system ascorbate-FeSO ${ }_{4}$. Circumstantial evidence suggests that the compounds, as shown for cercosporin, induce a lipoperoxidative degradation of the polyunsaturated fatty acids of cell membranes when irradiated by light, but at the same time, they are able to lower the lipoperoxidation induced by ferrous ions.
\end{abstract}

Cercosporin, a phytotoxin produced by several species of the genus Cercospora, ${ }^{1 \sim 6)}$ is a dihydroxy-perilenequinone ${ }^{7,8)}$ inducing, when irradiated by an incandescent light, a marked lipoperoxidative degradation of some natural and artificial biological membranes. ${ }^{9,10}$

In the present work, we studied the photodynamic activity of three compounds structurally related to cercosporin (iso-cercosporin, phleichrome, iso-phleichrome) and rubellin, a pigment possessing an anthraquinone-like structure. ${ }^{11,12)}$ Phleichrome and rubellin are two phytotoxins produced by Cladosporium phlei and Mycosphaerella rubella, respectively. ${ }^{11,12)}$ Mycosphaerella is the metagenetic state of the genus Cladosporium and Cercospora. ${ }^{13)}$

\section{MATERIALS AND METHODS}

Pea stem and rat liver mitochondria and microsomes were fractionated as described in a previous work. ${ }^{10)}$

Protein content was estimated by the biuret method. ${ }^{14)}$

Oxygen uptake was followed with a platinum electrode assembly of the Clark type. ${ }^{15)}$ Malondialdehyde (MDA) formation was determined by the thiobarbituric acid method of Wilbur et al. ${ }^{18)}$ as described by Ottolenghi;17) MDA content was calculated by measuring $\varepsilon=1.56 \times 10^{5} \mathrm{~cm}^{2} \mathrm{~mol}^{-1}$ at $532 \mathrm{~nm}$.

Cercosporin, iso-cercosporin, phleichrome, iso- phleichrome and rubellin were dissolved in absolute ethanol to give $4 \mathrm{mg} / \mathrm{ml}$ stock solutions. Ethanol in the incubation mixtures did not exceed $0.25 \%$.

\section{RESULTS AND DISCUSSION}

Figure 1 shows the effect of cercosporin, iso-cercosporin, phleichrome, iso-phleichrome and rubellin irradiated by an incandescent light on oxygen uptake in pea stem mitochondria. As previously observed for irradiated cercosporin, ${ }^{10}$ the compounds induced a marked increase of oxygen uptake which stopped in the dark. This indicates that a lipoperoxidative damage in the membranes of such organelles was triggered by light captured by the phytotoxic compounds.

The lipoperoxidation was also evaluated by measuring MDA formation in isolated pea stem and rat liver mitochondria and microsomes (Tables I and II). All the compounds, in the presence of light, induced the formation of different amounts of MDA. The lipoperoxidative effect was higher in rat liver than in pea stem mitochondria and microsomes. Both plant and animal microsomes were more sensitive than mitochondria to the lipoperoxidation. The addition to the incubation mixtures of butylated hydroxyanisole (BHA), a 


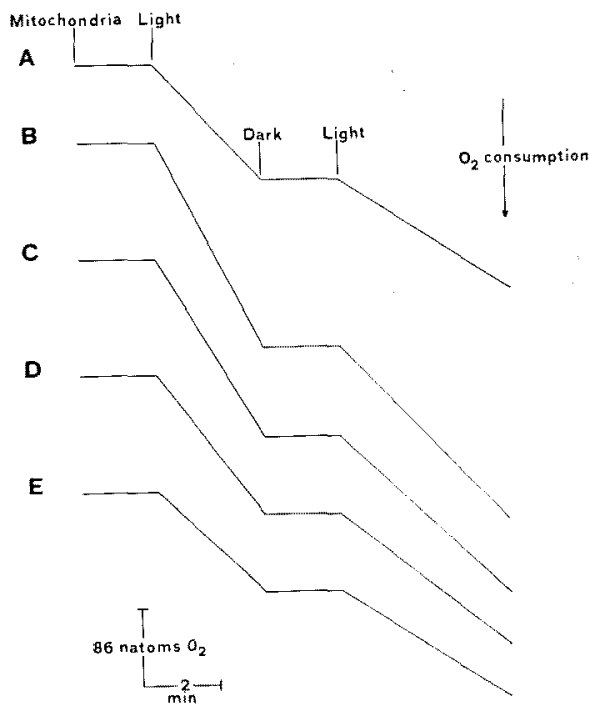

FIG. 1. Oxygen Uptake in Pea Stem Mitochondria Induced by Cercosporin (A), iso-Cercosporin (B), Phleichrome (C), iso-Phleichrome (D) and Rubellin(E).

The assay system consisting of $125 \mathrm{~mm} \mathrm{KCl}$ and $25 \mathrm{~mm}$ Tris- $\mathrm{HCl}$ buffer ( $\mathrm{pH} \mathrm{7.4)} \mathrm{contained} 1 \mathrm{mg} / \mathrm{ml}$ of mitochondrial protein. The compounds tested were added at the beginning and the concentration used was $10 \mu \mathrm{g} / \mathrm{ml}$. The reactions were carried out at $25^{\circ} \mathrm{C}$ with constant shaking and started by illumination with $200 \mathrm{~W}$ incandescent lamp at a distance of $20 \mathrm{~cm}$.

Table I. Lipoperoxidation on Pea Stem MrTochondria AND Microsomes INDUCED by Cercosporin-Structuraliy RELATED COMPOUNDS

\begin{tabular}{lllr}
\hline & & nmol MDA $\mathrm{mg}^{-1}$ & protein \\
\cline { 3 - 4 } & & $-\mathrm{BHA}$ & $+\mathrm{BHA}$ \\
\hline \multirow{2}{*}{ Mitochondria } & cercosporin & 0.58 & 0.10 \\
& iso-cercosporin & 3.42 & 0.15 \\
& phleichrome & 2.22 & 0.34 \\
& iso-phleichrome & 1.84 & 0.33 \\
& rubellin & 1.90 & 0.17 \\
\hline Microsomes & cercosporin & 3.68 & 1.45 \\
& iso-cercosporin & 4.82 & 1.74 \\
& phleichrome & 4.48 & 1.34 \\
& iso-phleichrome & 3.71 & 1.54 \\
& rubellin & 3.44 & 1.92 \\
\hline
\end{tabular}

Conditions as in Fig. 1. Mitochondrial and microsomal protein was $1 \mathrm{mg} / \mathrm{ml}$. BHA was present at $2 \cdot 10^{-4} \mathrm{M}$ concentration. MDA content of samples was corrected by subtracting control values.

known antioxidant, markedly lowered MDA formation in all membrane systems assayed.
TABLE II. Lipoperoxidation ON RAT LiVER MITOCHONDRIA AND MICROSOMES INDUCED by Cercosporin-Structurally RELATED COMPOUNDS

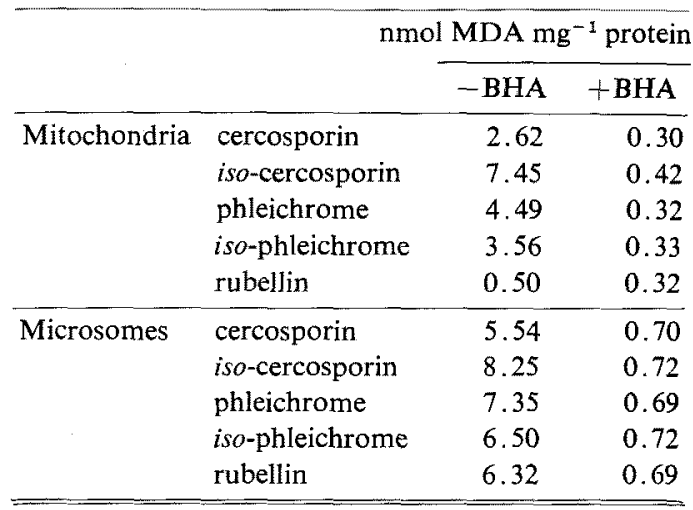

Conditions as in Fig. 1. Mitochondrial and microsomal protein was $1 \mathrm{mg} / \mathrm{ml}$. BHA was present at $2 \cdot 10^{-4} \mathrm{M}$ concentration. MDA content of samples was corrected by subtracting control values.

Table III. EfFect of Cercosporin-Structurally

RELATED COMPOUNDS ON THE LIPOPEROXIDATION INDUCED BY THE SYSTEM AsCORBATE-FeSO 4

\begin{tabular}{lc}
\hline & $\mathrm{nmol} M \mathrm{MA} \mathrm{mg}^{-1}$ protein \\
\hline None & 9.6 \\
Cercosporin & 6.4 \\
iso-Cercosporin & 6.4 \\
Phleichrome & 5.2 \\
iso-Phleichrome & 5.0 \\
Rubellin & 6.4 \\
\hline
\end{tabular}

The basic mixture was: $125 \mathrm{~mm} \mathrm{KCl}$ in $25 \mathrm{~mm}$ Tris- $\mathrm{HCl}(\mathrm{pH} 7.5)$ and $0.6 \mathrm{mg} / \mathrm{ml}$ of mitochondrial protein. The incubation with the peroxidizing system $0.2 \mathrm{~mm}$ ascorbate and $20 \mu \mathrm{M} \quad \mathrm{FeSO}_{4}$ was carried out for $60 \mathrm{~min}$ at $25^{\circ} \mathrm{C}$. MDA content of samples was corrected by subtracting control values.

Since cercosporin was found to lower the peroxidative processes catalysed by ferrous ions, ${ }^{101}$ we have tested the effect of the compounds examined on the peroxidizing activity of the system ascorbate-FeSO ${ }_{4}$ in pea stem mitochondria (Table III). As shown for cercosporin, the phytotoxic compounds decreased MDA formation induced by the chemical system.

In Fig. 2 are shown the absorption spectra of cercosporin, iso-cercosporin, phleichrome, iso-phleichrome and rubellin in the presence 


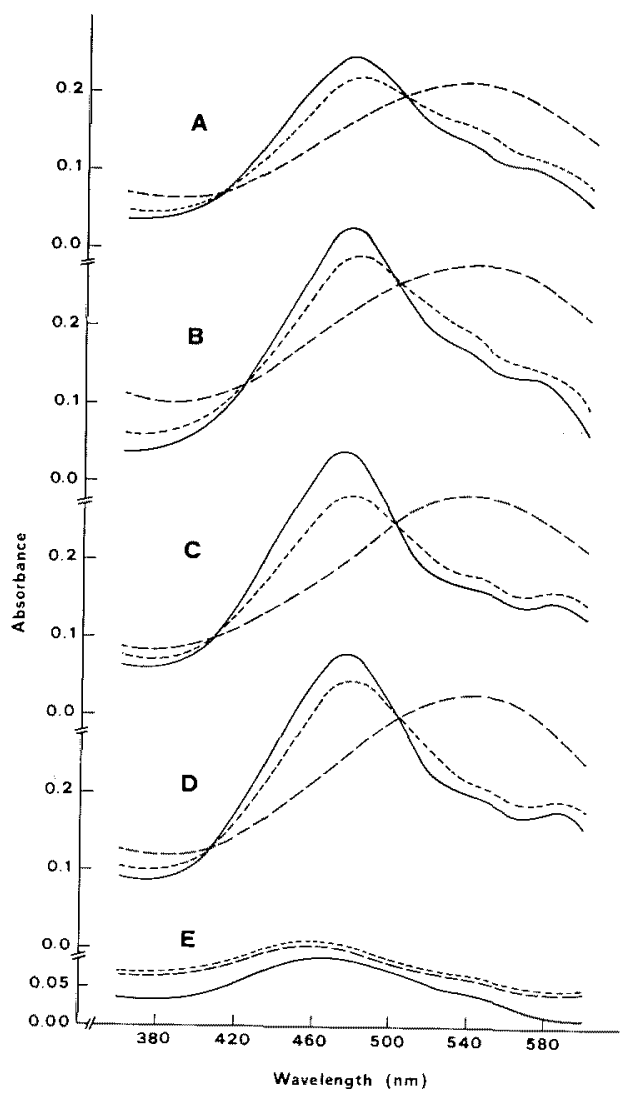

FIG. 2. Absorption Spectra of Cercosporin (A), iso-Cercosporin (B), Phleichrome (C), iso-Phleichrome (D) and Rubellin (E) in the Presence or Absence of Iron Ions.

The compounds $(10 \mu \mathrm{g} / \mathrm{ml})$ were dissolved in $25 \mathrm{~mm}$ Tris-HCl buffer ( $\mathrm{pH} \mathrm{7.4)} \mathrm{containing} 0.125 \mathrm{M} \mathrm{KCl}$ and read against the same medium. Compounds without iron ions, (-); compounds with $20 \mu \mathrm{M} \mathrm{FeSO}$, (-- ) ; compounds with $20 \mu \mathrm{M} \mathrm{FeCl}_{3}$, (-----).

or absence of iron ions. The phytotoxins showed the same maximum of absorption of cercosporin $(470 \mathrm{~nm})$. The addition of ferrous ions caused a marked shift of the maximum absorption of cercosporin, iso-cercosporin, phleichrome and iso-phleichrome toward longer wavelengths, while the addition of ferric ions induced less changes in the spectra of all compounds. The presence of the antioxidant butylated hydroxytoluene (BHT) or BHA both at $2 \cdot 10^{-4} \mathrm{M}$ concentration did not prevent the shift induced by ferrous ions, indicating that the change in the spectra induced by such an ion does not depend on an oxidation of the molecule of the compounds, but on a chelating action exerted by such molecules. Both ferrous and ferric ions caused only slight changes in the spectrum of rubellin without any change in its maximum of absorption.

The results show that iso-cercosporin, phleichrome, iso-phleichrome and rubellin possess a photodynamic activity on some plant and animal membrane systems which takes place with a mechanism of action similar to that postulated for cercosporin. ${ }^{10)}$ Their photodynamic activity appears linked to the quinonic nature of the molecule; the perilene-quinone structure seems to be more efficient than that anthraquinonic in inducing the lipoperoxidative damage. All phytotoxins tested lower the lipoperoxidation induced by ferrous ions, probably by chelating iron as indicated by the changes in their absorption spectra caused by ferric and ferrous ions.

Acknowledgments. Thanks are due to Drs. L. Merlini, G. Nasini, L. Camarda and G. Assante for the gift of phytotoxic compounds.

Thanks are also due to Ms. D. Ferrara for technical assistance.

\section{REFERENCES}

1) G. Assante, R. Locci, L. Camarda, L. Merlini and G. Nasini, Phytochem., 16, 243 (1977).

2) C. Balis and M. G. Payne, Phytopath., 61, 1477 (1971).

3) A. O. Fajola, Physiol. Plant Path., 13, 157 (1978).

4) S. Kuyama and T. Tamura, J. Amer. Chem. Soc., 79, 5725 (1957).

5) F.J.Linck and M. J. Geoghegan, Trans. Br. mycol. Soc., 69, 496 (1977).

6) K. Venkataramani, Phytopath. Z., 58, 379 (1967).

7) R. J. J. Ch. Lousberg, U. Weiss, C. A. Salemink, A. Arnone, L. Merlini and G. Nasini, Chem. Commun., 1971, 1463.

8) S. Yamazaki, A. Okubo, Y. Akiyama and K. Fuwa, Agric. Biol. Chem., 39, 287 (1975).

9) F. Macrì and A. Vianello, Plant, Cell and Environ., 2, 267 (1979).

10) L. Cavallini, A. Bindoli, F. Macri and A.Vianello, Chem. Biol. Interactions, 28, 139 (1979).

11) T. Yoshiara, T. Shimanuki, T. Araki and S. Sakamura, Agric. Biol. Chem., 39, 1683 (1975).

12) G. Assante, L. Camarda, L. Merlini and G. 
Nasini, 2nd Meeting on the Chemistry and Physiology of Phytotoxins, Italy, Padova, May, 1980, Phytopath. Medit., in press.

13) J. A. von Arx, The Genera of Fungi Sporulating in Pure Culture, J. Cramer, FL-9490 Vaduz, 1974, p. 137.

14) A. G. Gornall, C. J. Bardawill and M. M. David, J. Biol. Chem., 177, 751 (1949).
15) R. W. Estabrook, "Methods in Enzymology", Vol. X, ed. by S. P. Colowick and N. O. Kaplan, Academic Press, New York and London, 1967, p. 41.

16) K. M. Wilbur, F. Bernheim and O. W. Shapiro, Arch. Biochem. Biophys., 24, 305 (1949).

17) A. Ottolenghi, ibid., 79, 355 (1959). 